IRA-International Journal of Management \& Social Sciences

ISSN 2455-2267; Vol.06, Issue 02 (2017)

Pg. no. 314-323

Institute of Research Advances

https://research-advances.org/index.php/RAJMSS

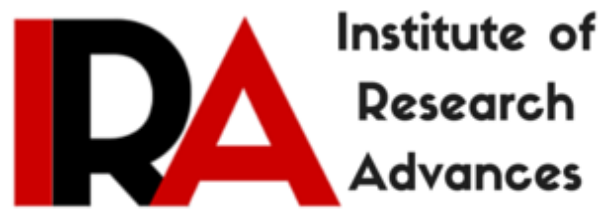

\title{
Dream Guys of Demographic Dividend and Their Economic Preferences
}

\author{
Dr. Mamta Manshani \\ Associate Professor, Oriental College of Management, Bhopal (MP), India. \\ Dr. (Prof) P.K.Chopra \\ Director, Oriental College of Management, Bhopal (MP), India.
}

Type of Review: Peer Reviewed.

DOI: http://dx.doi.org/10.21013/jmss.v6.n2.p16

\section{How to cite this paper:}

Manshani, M., \& Chopra, P. (2017). Dream Guys of Demographic Dividend and Their Economic Preferences. IRA-International Journal of Management \& Social Sciences (ISSN 24552267), 6(2), 314-323. doi:http://dx.doi.org/10.21013/jmss.v6.n2.p16

(C) Institute of Research Advances

(cc) EY-NC

This work is licensed under a Creative Commons Attribution-Non Commercial 4.0 International License subject to proper citation to the publication source of the work.

Disclaimer: The scholarly papers as reviewed and published by the Institute of Research Advances (IRA) are the views and opinions of their respective authors and are not the views or opinions of the IRA. The IRA disclaims of any harm or loss caused due to the published content to any party. 


\section{ABSTRACT}

India is the nation of Young people with lots of dream and aspirations. If they have the skills, right education, health and real choices in life than they are the one who drives the nation towards prosperity. The economic and social progress of the country mainly depends on its young people.

By 2020, India is set to become the world's youngest country with 64 per cent of its population in the working age group. With the West, Japan and even China aging, this demographic potential offers India and its growing economy an unprecedented edge that economists believe could add a significant 2 per cent to the GDP growth rate. Demographic dividend occurs when the proportion of independent people in the total population is larger than dependent people because this indicates that more people have the potential to be productive and contribute to growth of the economy.

This paper aims to find out and study personality and economic preferences of youth of India which is likely to benefit from demographic dividend.

Keywords: Demographic Dividend, Young India, Economic preferences

\section{JEL Classification: R11, R20, D60}

\section{INTRODUCTION}

India is a nation of youth having dreams and aspirations. Although China has overall largest population, India has the world's largest youth population with 35 crore 10-24 year-olds. China is second with 27 crore young people, followed by Indonesia (6.7 crore), the US (6.5 crore) and Pakistan (5.9 crore). Young people are the innovators, creators, builders and leaders of the future, only if they have skills, health, decision-making, and real choices in life. It is said that developing countries with large youth populations would be superpower of future.

Demographic dividend occurs when the proportion of independent people in the total population is larger than dependent people because this indicates that more people have the potential to be productive and contribute to growth of the economy. According to the United National population research, during the last four decades the countries of Asia and Latin America have been the main beneficiaries of the demographic dividend. Countries of Europe, Japan and USA have an older population due to low birth rates and low mortality rates. China's one child policy has reversed the demographic dividend it enjoyed since the mid 1960s according to a World Bank global development report.

Falling birth rates reduce the overall expenditure required to provide basic necessities for the under 14 age group (which is yet to be productive) and increased longevity ensures that a large proportion of the population are within the 15-59 age group (working population). Dependency ratio refers to the proportion of non -working population on the working population. In India this ratio is around 0.6. Every third person in an Indian city today is a youth. In about seven years, the median age of individual in India will be 29 years, very likely a city-dweller, making it the youngest country in the world.

But this Demographic Dividend will not automatically contribute to growth it requires focused effort based on policy of economic development. The main mission of policy should be providing meaningful words to youth. 
This paper aims to find out and study personality and economic preferences of youth of India which is likely to benefit from demographic dividend.

\section{Youth preferences towards their looks}

Today's Youth is more conscious about their looks. As present era is of Facebook, Instagram, Twitter, they share everything they do along with their thoughts. Youth motivation depends on likes, comment on photo's they share. So everybody wants to look good. A recent article in The New York Times noted, "Skin-lightening products are by far the most popular product in India's fast-growing skin care market, so manufacturers say they ignore them at their peril." In India a notion of beauty is fair skin, there still a bias for fair skin especially at the time of choosing a life partner.

Being good looking has a positive impact on our lives. It helps us attract sexual partners, people like being with us and they ascribe good qualities to our character. Being good looking also helps our employment prospects. A research from the US and UK has now established that being perceived to be attractive improves our chances of obtaining work, and boosts our pay and career prospects.

A recent report states that paying attention to your appearance and maintaining mutual attraction is, in fact, key to keeping the spark alive. And this holds true for both men and women alike.

\section{Youth aspiration towards Occupation \& Income}

In a survey conducted by PHD Research Bureau, it was observed that regarding plans for career development of youth, 55\% of the respondents said that after the completion of their graduation/post graduation they would prefer to join job to become self -sustainable financially as early as possible while $29 \%$ of the respondents were thinking about the further higher studies followed by entrepreneurship (12\%) and family business (4\%). Of the total job aspirants, around $44 \%$ of the students responded that they would prefer private sector jobs for excellent growth opportunities, fabulous remuneration packages and challenging roles. While $36 \%$ respondents preferred the government jobs as they prefer a good combination of job security and privileges, stability and satisfaction. The remaining $20 \%$ surveyed students were indifferent between the public or private sector jobs

\section{$\underline{\text { Objectives }}$}

- To find out youth preference on appearance. ( How they want to look like)

- To study and understand the occupational choices of youth and their preferences.

- To find out and study the aspiration of youth towards Income expectations.

\section{Research Methodology}

The research undertaken was exploratory in nature. The data was collected through survey method. Survey method was adopted to develop an approach towards the problem so as to understand the preference of youth towards their preferred looks. Youth aspiration towards Income and occupational preferences were also surveyed. Questionnaire method was used for taking responses from youth. Using convenient sampling 50 youth (student \& faculty members of MBA course) from Bhopal city was selected for primary data collection. Secondary data was used for developing research base. Various studies such as NCAER survey, Census of India, United Nations "World Population Prospects": Country Profile - India" etc were studied for understanding general scenario on Demographic dividend and youth preferences. 
Data was analyzed through SPSS. Mean, Standard deviation used for data interpretation. Friedman Test, Sign test is used for hypothesis testing.

\section{Data Analysis \& Interpretation}

H1: Youths want to look like film stars and their preference is significantly higher than other looks H01: Null Hypothesis: There is no significant difference in youth Preference towards looks.

Descriptive Statistics 1.1

\begin{tabular}{|l|l|l|l|l|l|}
\hline & N & Mean & Std. Deviation & Minimum & Maximum \\
\hline Film star & 33 & 5.09 & 2.127 & 1 & 8 \\
Sports star & 33 & 6.27 & 2.050 & 2 & 9 \\
Political leader & 33 & 4.00 & 2.179 & 0 & 8 \\
Business personality & 33 & 7.73 & 1.892 & 2 & 10 \\
Any other & 33 & 5.21 & 2.870 & 0 & 10 \\
\hline
\end{tabular}

Friedman Test

Table 1.2:Ranks

\begin{tabular}{|l|l|}
\hline & Mean Rank \\
\hline Film star & 2.56 \\
Sports star & 3.45 \\
Political leader & 1.92 \\
Business personality & 4.39 \\
Any other & 2.67 \\
\hline
\end{tabular}

Table1.3:Test

Statistics ${ }^{\mathrm{a}}$

\begin{tabular}{|l|l|}
\hline N & 33 \\
Chi-Square & 49.700 \\
df & 4 \\
Asymp. Sig. & .000 \\
\hline
\end{tabular}

a. Friedman Test

This test shows us that there is a statistically significant finding. The p-value (asymp. Sig. in the table above) is $p=0.000$. (A p-value less than 0.05 is said to be statistically significant). The calculated value for Chi is 49.7 at 4 degree of freedom. And tabulated value at $4 \mathrm{df}$ is $\mathrm{P}(0.05)=7.815$ and $\mathrm{P}(0.01)=$ 11.345. As the calculated value is higher than the tabulated value Results are significant. So null hypothesis is rejected but alternate hypothesis is also not correct as table $1.1 \& 1.2$ shows that youth wants to looks like Business Personality with a highest mean of 7.86 with lowest standard deviation of 1.8 and with a mean rank of 4.39 .

H2: Physical characteristics like very fair complexion, 6 feet (boys) 5'6" (girls) height and weight between $60-70 \mathrm{kgs}$ are the favorites of dream guys of India

H02: There is no significant difference in youth preference towards their looks (Complexion, height, \& weight) 
Table 1.4: Descriptive Statistics

\begin{tabular}{|l|l|l|l|l|l|}
\hline $\begin{array}{l}\text { Comple } \\
\text { xion }\end{array}$ & & Mean & $\begin{array}{l}\text { Std. } \\
\text { Deviati } \\
\text { on }\end{array}$ & $\begin{array}{l}\text { Minimu } \\
\text { m }\end{array}$ & $\begin{array}{l}\text { Maxim } \\
\text { um }\end{array}$ \\
\hline V.Fair & 47 & 5.32 & 2.704 & 0 & 10 \\
Fair & 47 & 6.89 & 2.581 & 0 & 10 \\
Whitish & 47 & 6.45 & 2.492 & 0 & 10 \\
Dark & 47 & 4.43 & 2.329 & 0 & 9 \\
\hline
\end{tabular}

Table 1.5: Ranks

\begin{tabular}{|l|l|}
\hline & Mean Rank \\
\hline V.Fair & 2.24 \\
Fair & 3.27 \\
Whitish & 2.82 \\
Dark & 1.67 \\
\hline
\end{tabular}

$\begin{aligned} & \text { Table 1.6: Test } \\
& \text { Statistics }\end{aligned}$
\begin{tabular}{|l|l|}
\hline N & 47 \\
Chi-Square & 45.514 \\
df & 3 \\
Asymp. Sig. & .000 \\
\hline
\end{tabular}

This test shows us that there is a

a. Friedman Test

statistically significant finding. The p-value (asymp. Sig. in the table 1.6) is $p=0.000$. (A p-value less than 0.05 is said to be statistically significant). The calculated value for Chi is 45.5 at 3 degree of freedom. And tabulated value at $3 \mathrm{DF}$ is $\mathrm{P}$ $(0.05)=7.815$ and $P(0.01)=11.345$. As the calculated value is higher than the tabulated value Results are significant. So null hypothesis is rejected and alternate hypothesis is accepted that youth prefer fair complexion. From the table 1.5, it is evident that fair complexion with a highest means of 6.89 and mean rank of 3.27 is preferred by today's youth.

Table 1.7: Descriptive Statistics

\begin{tabular}{|l|l|l|l|l|l|}
\hline Height & $\mathrm{N}$ & Mean & Std. Deviation & Minimum & Maximum \\
\hline $4.5-5$ & 48 & 3.98 & 2.572 & 0 & 9 \\
$5.1-5.6$ & 50 & 6.52 & 2.367 & 0 & 10 \\
$5.7-6$ & 50 & 7.50 & 2.053 & 0 & 10 \\
Above 6 & 49 & 4.63 & 2.963 & 0 & 10 \\
Gender & 50 & 1.60 & .495 & 1 & 2 \\
\hline
\end{tabular}

From the above table 1.7, majority of youth prefer height between $5.7-6$ feet with highest mean of 7.5. This preference is analyzed gender wise also.

Table 1.8: Ranks

\begin{tabular}{|ll|l|l|l|}
\hline & Gender & $\mathrm{N}$ & Mean Rank & Sum of Ranks \\
\hline $4.5-5$ & Male & 20 & 21.95 & 439.00 \\
& Female & 28 & 26.32 & 737.00 \\
& Total & 48 & & \\
\hline $5.1-5.6$ & Male & 20 & 22.58 & 451.50 \\
& Female & 30 & 27.45 & 823.50 \\
& Total & 50 & & \\
\hline
\end{tabular}




\begin{tabular}{|ll|l|l|l|}
\hline $5.7-6$ & Male & 20 & 26.98 & 539.50 \\
& Female & 30 & 24.52 & 735.50 \\
& Total & 50 & & \\
\hline Above 6 & Male & 20 & 26.12 & 522.50 \\
& Female & 29 & 24.22 & 702.50 \\
& Total & 49 & & \\
\hline
\end{tabular}

Table 1.9: Mann-Whitney Test Statistics

\begin{tabular}{|l|l|l|l|l|}
\hline & $4.5-5$ & $5.1-5.6$ & $5.7-6$ & Above 6 \\
\hline Mann-Whitney U & 229.000 & 241.500 & 270.500 & 267.500 \\
Wilcoxon W & 439.000 & 451.500 & 735.500 & 702.500 \\
Z & -1.081 & -1.180 & -.597 & -.460 \\
$\begin{array}{l}\text { Asymp. Sig. } \\
\text { tailed) }\end{array}$ & $(2-280$ & .238 & .550 & .646 \\
\hline
\end{tabular}

a. Grouping Variable: Gender

Null hypothesis is tested through Mann-Whitney Test using SPSS 16.0. Mean rank for males is higher in (5.7 -6 feet) with 26.98 and mean rank for females is higher in (5.1-5.6 feet) category i.e 27.45.

The $\mathrm{Z}$ is the standardized score associated with the significance value. In all the cases, $\mathrm{p}$ value is greater than the alpha value (.005), so there is no significant difference in preference of youth towards their height with respect to Gender (Table 1.8 \& 1.9).

Table 1.10: Descriptive Statistics

\begin{tabular}{|l|l|l|l|l|l|}
\hline Weight & $\mathrm{N}$ & Mean & Std. Deviation & Minimum & Maximum \\
\hline Less than 50 & 47 & 4.40 & 2.585 & 0 & 10 \\
$50-60$ & 50 & 7.50 & 2.140 & 1 & 10 \\
$60-70$ & 49 & 6.84 & 2.192 & 1 & 10 \\
Above 70 & 46 & 3.63 & 2.870 & 0 & 10 \\
\hline
\end{tabular}

From the above table 1.10, majority of youth prefer weight between 50- 60 feet with highest mean of 7.5. This preference is analyzed gender wise also.

Table 1.11: Ranks

\begin{tabular}{|ll|l|l|l|}
\hline \multicolumn{2}{|c|}{ Gender } & $\mathrm{N}$ & Mean Rank & Sum of Ranks \\
\hline Less than 50 & Male & 19 & 20.82 & 395.50 \\
& Female & 28 & 26.16 & 732.50 \\
& Total & 47 & & \\
\hline $50-60$ & Male & 20 & 23.40 & 468.00 \\
& Female & 30 & 26.90 & 807.00 \\
& Total & 50 & & \\
\hline $60-70$ & Male & 20 & 25.38 & 507.50 \\
& Female & 29 & 24.74 & 717.50
\end{tabular}




\begin{tabular}{|c|c|c|c|c|}
\hline & Total & 49 & & \\
\hline \multirow[t]{3}{*}{ Above 70} & Male & 20 & 25.98 & 519.50 \\
\hline & Female & 26 & 21.60 & 561.50 \\
\hline & Total & 46 & & \\
\hline
\end{tabular}

Table 1.12: Test Statistics ${ }^{\mathrm{a}}$

\begin{tabular}{|l|l|l|l|l|}
\hline & Less than 50 & $50-60$ & $60-70$ & Weight4 \\
\hline Mann-Whitney U & 205.500 & 258.000 & 282.500 & 210.500 \\
Wilcoxon W & 395.500 & 468.000 & 717.500 & 561.500 \\
$Z$ & -1.329 & -.854 & -.156 & -1.108 \\
$\begin{array}{l}\text { Asymp. Sig. } \\
\text { tailed) }\end{array}$ & .184 & .393 & .876 & .268 \\
\hline
\end{tabular}

a. Grouping Variable: Gender

Null hypothesis is tested through Mann-Whitney Test. The $\mathrm{Z}$ is the standardized score associated with the significance value. In all the cases, $\mathrm{p}$ value is greater than the alpha value (.005), so there is no significant difference in preference of youth towards their height with respect to Gender (Table $1.11 \& 1.12$ ). At last we conclude that majority of the respondents want to be fit and weight around 60 whether male or females.

\section{H3: Youth today want to serve preferably in a Government job rather than private job}

H03: Null Hypothesis: There is no significant difference in preference over Government job and private job

Table 1.13: Descriptive Statistics

\begin{tabular}{|l|l|l|l|l|l|}
\hline & $\mathrm{N}$ & Mean & Std. Deviation & Minimum & Maximum \\
\hline Government Job & 50 & 6.9264 & 1.59998 & 1.33 & 9.67 \\
Private Job & 50 & 7.7000 & 1.63819 & 2.00 & 10.00 \\
\hline
\end{tabular}

From the above Descriptive table, it is evident that mean of Preferences towards Government job (6.9) is less than Private job (7.7). For further analysis and hypothesis testing data sign test is used. 


\begin{tabular}{|ll|l|}
\hline \multicolumn{2}{|l|}{ Table1.14: Frequencies } & N \\
\hline $\begin{array}{l}\text { Private Job - Government } \\
\text { Job }\end{array}$ & 18 \\
& Differences $^{\mathrm{a}}$ & \\
& Positive $^{\mathrm{b}}$ & 31 \\
& Differences $^{\mathrm{s}}$ & \\
& Ties $^{\mathrm{c}}$ & 1 \\
& Total & 50 \\
\hline
\end{tabular}

a. Private Job < Government Job

b. Private Job > Government Job

c. Private Job $=$ Government Job

\begin{tabular}{|lr|l|}
\hline $\begin{array}{l}\text { Table1.15: } \\
\text { Statistics }\end{array}$ & Test & $\begin{array}{l}\text { Private Job } \\
\text { Government } \\
\text { Job }\end{array}$ \\
\hline $\begin{array}{l}\text { Z } \\
\text { Asymp. Sig. } \\
\text { tailed) }\end{array}$ & $\quad(2-$ & -1.714 \\
\hline
\end{tabular}

a. Sign Test

From the above table 1.14 it is evident that in 31 cases participant prefer Private Job over Government job, in 18 cases respondent prefer Government job over Private Job and in one case respondent equally prefer both.

As in table 1.15 (Test Statistics ${ }^{\mathbf{a}}$ ) p valve (.086) is greater than .05 significance value so null hypothesis is rejected or we conclude that majority of youth prefer Private Job over Government job.

\section{H4: Dream guys prefer to serve rather than doing self business}

H04: Null Hypothesis: There is no significant difference in youth preference towards Job and Business

Table1.16: Descriptive Statistics

\begin{tabular}{|c|c|c|c|c|c|c|c|c|c|}
\hline & $\mathrm{N}$ & & Mean & \multicolumn{2}{|c|}{ Std. Deviation } & Minimum & \multicolumn{2}{|c|}{ Maximum } & \\
\hline Business & 50 & & 8.00 & \multicolumn{2}{|c|}{1.979} & 4 & \multicolumn{2}{|l|}{10} & \\
\hline Job & 50 & & 7.3002 & \multicolumn{2}{|c|}{1.29091} & 2.33 & 9.67 & & \\
\hline \multicolumn{2}{|c|}{ Table 1.17: } & \multicolumn{3}{|c|}{ Frequencies } & $\mathrm{N}$ & \multicolumn{4}{|c|}{ Table 1.18: Test Statistics ${ }^{a}$} \\
\hline \multirow{4}{*}{\multicolumn{2}{|c|}{ Job - Business }} & \multicolumn{3}{|c|}{ Negative Differences $^{\mathrm{a}}$} & 33 & & & Job - & usiness \\
\hline & & \multicolumn{3}{|c|}{ Positive Differences $^{b}$} & 17 & \multicolumn{2}{|l|}{$\mathrm{Z}$} & -2.12 & \\
\hline & & \multicolumn{3}{|l|}{ Ties $^{c}$} & 0 & $\begin{array}{l}\text { Asymp. } \\
\text { (2-tailed) }\end{array}$ & Sig. & .054 & \\
\hline & & \multicolumn{3}{|l|}{ Total } & 50 & \multicolumn{2}{|c|}{ a. Sign Test } & & \\
\hline
\end{tabular}
a. Job $<$ Business
b. Job > Business
c. Job $=$ Business

From the above table1.17 it is evident that in 33 cases participant youth prefer Self Business over doing Job, in 17 cases respondent prefer to do job government or private over doing self business. As in table $1.18, \mathrm{p}$ value $=.054$ which is greater than .05 significance value so null hypothesis is rejected or we conclude that today's youth prefer to do business over job. 


\section{H5: Youth of today wants to earn 1 lack rupees a month}

\section{H5: There is no significant difference in youth preference towards Income}

Table 1.19: Descriptive Statistics

\begin{tabular}{|l|l|l|l|l|l|l|}
\hline & N & Minimum & Maximum & Mean & Std. Deviation & Variance \\
\hline 1-5 lakhs & 50 & 0 & 10 & 5.50 & 2.525 & 6.378 \\
6-8 lakhs & 50 & 2 & 10 & 7.46 & 1.460 & 2.131 \\
9-12 lakhs & 50 & 2 & 10 & 7.46 & 2.092 & 4.376 \\
13 and above & 50 & 1 & 10 & 8.26 & 2.008 & 4.033 \\
Valid N (listwise) & 50 & & & & & \\
\hline
\end{tabular}

From the above descriptive statistic, it is evident that today's youth preferred higher income of 13 lac /annum with mean of 8.26 which highest among the group and low S.D of 2.0. So we can accept alternate hypothesis that Youth of today wants to earn 1 lac rupees a month.

\section{Conclusion}

Young Indian is very conscious about his/her looks. Both men and women aspire to look fairer and smarter. From this study we find that the majority of the youth prefer to sport normal hair length, and have tall and slim physique. This paper reveals that youth of India prefers to look like business personality or tycoon more than to look like a politician or a film star.

From the study it is revealed that majority of youth prefers private job over government job because of high income expectations. Both males and females want to earn Rs.10 lakhs per annum or above. They also wish to preferably do their own business rather than serving others.

Never before have there been so many young people in India so it has a huge potential for economic and social growth. A demographic dividend of this magnitude has the potential to lift hundreds of crores of people above poverty line, raise living standards and push Indian economy forward. So for the purpose of finding the youth preferences, this study was conducted. To a great extent one can say that dream guys of demographic dividend wish to be tall, smart, and fair with a job or business of fetching them above 10 lakhs per annum. We hope India is going to achieve a new height of growth with such dream guys in the coming 5 yrs.

\section{References}

1. Acemoglu, D., J.A. Robinson and S. Johnson. 2001. The Colonial Origins of Comparative Development: An Empirical Investigation. American Economic Review, volume 91, December, p. 1369-1401

2. Aiyar, S., A. Mody. (2011). The Demographic Dividend: Evidence from the Indian States. IMF Working Paper. No 38. IMF. Washington D.C.

3. Barro, R., and Sala-I-Martin. (1995) Economic Growth, New York: McGraw-Hill.

4. Basu, K. (2007). India's Demographic Dividend. BBC News (Online). 25 July. Available from: http://news.bbc.co.uk/1/hi/world/south_asia/6911544.stm 
5. Bauer, J. (2001). Demographic change, development, and the economic status of women in East Asia, in A. Mason. Population Change and Economic Development in East Asia. Challenges Met, Opportunities Seized, Stanford University Press, p. 359- 384.

6. Birdsall, N., A. Kelley and S. Sinding. (2001). Population Matters: Demographic Change, Economic Growth and Poverty in the Developing World. Oxford University Press

7. Keynes, J.M., (1936). The General Theory of Employment, Interest and Money. New York. Harcourt, Brace and Company.

8. Kuznets, S., (1967). Population and Economic Growth. Proceedings of the American Philosophical Society, Vol. 111, p. 170-193.

9. Lee, R. D. (2003).The Demographic Transition: Three Centuries of Fundamental Change. Journal of Economic Perspectives 17: 167-90.

10. Registrar General of India (2011). Census of India Data (Online). Available from http://censusindia.gov.in/

11. Times of India, "India has 40 percent drop-out rate in elementary schools: Report", (November 14,2013)

12. "World Bank Report". "World Bank Report on Malnutrition in India"(2009). 